\title{
ЕФЕКТИВНІСТЬ РЕКОНСТРУКЩІї ТВАРИННИЦЬКИХ БУДІВЕЛЬ 3 ВИРОБНИЦТВА ЯЛОВИЧИНИ ЗА УМОВИ ДОТРИМАННЯ НОРМ ТЕХНОЛОГІЧНОГО ПРОЕКТУВАННЯ
}

\author{
Варпіховський Р. Л., кандидат сільськогосподарських наук \\ Вінницький національний аграрний університет
}

DOI: https://doi.org/10.31435/rsglobal_sr/31102019/6748

\section{ARTICLE INFO}

Received 17 August 2019

Accepted 19 October 2019

Published 31 October 2019

\section{KEYWORDS}

cattle,

technology,

content,

fattening of young,

the microclimate stage.

\begin{abstract}
Studies have established the content of young cattle under condition of use of the building for livestock $12 \times 62 \mathrm{~m}$ with a loose method of content stay in the pits over tethered for a liveweight gain of $10.0 \%$ at a lower cost of feed and labor, respectively, $5.2 \%$ and 57.8 per cent.

How factor using a 2-stage cultivation technology fattening of young cattle allows to increase live weight of animals and to 17 -month age $-406,2 \mathrm{~kg}$, an increase of $64.2 \mathrm{~kg}$, or $15.8 \%$, comparing with the outdated 3-stage technology, which provides higher profitability on the level of profitability of beef production of $33.3 \%$, an increase of $22.2 \%$.

It is established that the comparative evaluation of the safety method of keeping of young cattle with loose housing in cubicles showed that loose housing option: cost of feed was less than $5.2 \%$ and labor costs at 57.8 per cent, the level of profitability that was higher by $18.31 \%$.

So, offer producing use of the existing method of keeping loose with the rest of the animals in the pits for fattening of young cattle with the use of feed tables, with the cost of feed per $1 \mathrm{~kg}$ of weight gain 12 food. units and costs of labor in $1 \mathrm{CWT}$. increase in body weight of 3.25 people.
\end{abstract}

Citation: Варпіховський Р. Л. (2019) Efektyvnist Rekonstruktsii Tvarynnytskykh Budivel z Vyrobnytstva Yalovychyny za Umovy Dotrymannia Norm Tekhnolohichnoho Proektuvannia. Science Review. 8(25). doi: 10.31435/rsglobal_sr/31102019/6748

Copyright: (C) 2019 Варпіховський Р. Л. This is an open-access article distributed under the terms of the Creative Commons Attribution License (CC BY). The use, distribution or reproduction in other forums is permitted, provided the original author(s) or licensor are credited and that the original publication in this journal is cited, in accordance with accepted academic practice. No use, distribution or reproduction is permitted which does not comply with these terms.

Постановка проблеми. Сьогодні в більшості господарств виробництво яловичини не відповідає інноваційним підходам утримання худоби. Використовується застаріла модель неефективного прив'язного способу утримання молодняку, а порушення технологічних та гігієнічних параметрів вирощування і відгодівлі надремонтного молодняку великої рогатої худоби призводить до збиткового виробництва яловичини.

Актуальність теми. За сучасних вимог ставиться завдання щодо створення простих, дешевих і енергоефективних моделей виробничого процесу, за якого можна буде отримати якісну яловичину від здорових тварин у короткий проміжок часу. Усі технологічні витрати на роздачу кормів, видалення гною, на утримання повинні бути доведені до мінімуму через оптимізацію процесу виробництва та введення нових технологічних рішень і механічних засобів.

Аналіз останніх досліджень і публікацій. Інтенсивні технології відгодівлі молодняку великої рогатої худоби повинні бути наближені до природних, де тварини вільно рухаються у зоні відпочинку, годівлі та споживання води $[1,2]$.

Необхідно особливу увагу приділяти реконструкції старих тваринницьких приміщень враховуючи параметри мікроклімату та підбираючи сучасну механізацію трудомістких процесів, що в свою чергу, має особливе значення для невеликих ферм із закінченим циклом виробництва. 
Таким чином, для підвищення ефективності виробництва яловичини необхідно інтенсифікувати відгодівлю надремонтного молодняку молочних i комбінованих порід. Наукові обгрунтування розробок енергоощадних технологій дозволять, збиткове виробництво яловичини, у більшості тваринницьких підприємств, перевести на прибуткове. Тому, проведення ескізних пошуків реконструкцій тваринницьких будівель для виробництва яловичини виходять із технологічних процесів, удосконалення окремих елементів в технології виробництва яловичини в умовах невеликих ферм; вирощування і використання молодняку молочних і комбінованих корів для підвищеного виробництва яловичини $[5,6]$.

Згідно зі стандартами [2], традиційна технологія вирощування молодняку великої рогатої худоби передбачає три стадії: перша молочна (до 4-6 місяців), друга - дорощування, третя - відгодівля. У зв'язку з цим застосовується різноманітна годівля: помірна (в молочний), низька (при дорощуванні) і висока (на відгодівлі) зі значними витратами зернових концентратів у раціоні з метою компенсації спаду приросту і підвищення вгодованості.

За цієї технології, як правило отримують низькі середньодобові прирости на етапі дорощування, нераціонально використовуються корма та підвищується собівартість яловичини - виробництво є збитковим.

Пошуки резервів збільшення виробництва яловичини за рахунок застосування інтенсивного вирощування молодняку великої рогатої худоби цікавило багатьох дослідників, таких як: В.Г. Пруднікова [9], І.С. Трончука [10]. Двостадійна технологія вирощування молодняку великої рогатої худоби на м'ясо, включає дві стадії - молочну і післямолочну - до реалізації при максимальному споживанні об'ємистих кормів і оптимізації витрат зернових концентратів.

Метою досліджень $\epsilon$ моделювання технологічних процесів у різних виробничих умовах, реконструкція будівель та розробка проектного варіанту технології виробництва яловичини від надремонтного молодняку в умовах промислових господарств Барського, Літинського та Вінницького районів Вінницької області та на базі ДПДГ «Шевченківське» с. Денихівка Тетіївського району Київської області.

Об'єкти та методика досліджень. Згідно норм технологічного проектування (ВНТПАПК-01.05) були визначені параметри групових кліток для розміщення надремонтного молодняку великої рогатої худоби для відгодівлі по 40 голів, утримання безприв'язне 3 відпочинком у боксах із зоною годівлі із годівельного столу або залізобетонного жолоба та мобільною роздачею кормів один раз на добу. Видалення гною здійснюється бульдозерами у гноєсховище або транспортерами типу ТСН.

Годівля надремонтного молодняку у період відгодівлі проводилась у відповідності до норм і раціонів годівлі сільськогосподарських тварин (Ібатуллін I.І. та ін., 2003) [8].

Регулювання мікроклімату - передбачено за допомогою спеціальних шторок на вікнах та світлово-вентиляційних ліхтарів.

Формування дослідних груп тварин і розрахунки економічної ефективності за методикою Кононенка В.К. та ін. (2000) [3].

Телят 3 добового віку до 2-х місячного віку вирощували за холодного методу в індивідуальних або групових клітках на 5 голів, розпочинали з відділення профілакторного типу, де зберігається стабільна температура на рівні $20^{\circ} \mathrm{C}$ при відносній вологості повітря - $75 \%$, що позитивно впливає на енергію росту і збереження поголів'я тварин української чорно-рябої молочної породи.

А також проводили дослідження на групі тварин за безприв'язного утримання їх на глибокій підстилці. Для досліду виділено дві групи: контрольна (тристадійна технологія) та друга дослідна (двостадійна) по 16 голів у кожній групі бугайців української чорно-рябої молочної породи.

За більш ефективного використання площі будівлі та дотриманні норм технологічного проектування, а саме за двостадійної технології: молочний період та дорощування (післямолочний): перший - від народження до 8-місячного віку, другий - від 8- до 17-місячного віку.

Результат досліджень. Ефективність годівлі тварин суттєво залежить від вирішення питань щодо роздавання кормів. Цей процес за трудомісткістю займає від 25 до $35 \%$ всіх затрат праці на виробництво яловичини, що пов'язано із процесами доставки і роздавання кормів при виконанні значного обсягу робіт.

Так, на кожні 100 голів великої рогатої худоби потрібно щодоби роздавати 3-4 т кормів, причому весь годівельний вантаж своєчасно доставляється і нормовано розподіляється між тваринами. Порушення цих умов різко знижує ефективність інших технологічних заходів.

Проведенні дослідження свідчать, що затримка при годівлі молодняку великої рогатої худоби до 15 хвилин практично не призводить до помітних втрат продуктивності, але через 20- 
хвилин знижає прирости живої маси до 2,5\%. Перетримка на 30 хвилин супроводжується зниженням приростів до 5\%, а при перервах у роботі відповідного обладнання 1,5-2 години втрати продукції становлять 16-22\%.

Досліджуючи поведінкові реакції Це пов'язано із стресовими ситуаціями біля годівниць при безприв'язному утриманні молодняку великої рогатої худоби. При розробках засобів механізації роздавання кормів виходили із вимог:

- забезпечення заданого дозування та рівномірності видачі всіх видів кормів;

- можливість дозування корму кожній тварині окремо або групі тварин 3 рівними нормами споживання;

- робочі органи кормороздавача не повинні погіршувати якість (додаткове подрібнення, забруднення тощо) чи допускати втрати кормів;

- $\quad$ не створювати небезпеки для тварин і обслуговуючого персоналу, бути простими в експлуатації та обслуговуванні, надійними і довговічними в роботі;

- забезпечувати можливість автоматизації технологічних процесів.

Допустимі відхилення від заданої норми видачі для стеблових кормів повинні бути в межах $\pm 15 \%$, а концентрованих - $\pm 5 \%$. Незворотні втрати корму в процесі роздавання не перевищують $1 \%$.

Тривалість циклу роздавання кормів в одному приміщенні мобільними засобами не повинна перевищувати 30 хв.

Кормороздавачі повинні відзначатися універсальністю щодо можливості роздавання різних видів кормів у межах однієї ферми та регулювання норми видачі від мінімального до максимального значень, а також високою продуктивністю; не створювати надмірного шуму в приміщенні; легко очищатися від залишків корму та бруду; мати строк окупності не більше двох років і коефіцієнт готовності не менше 0,98.

Виходячи із розмірів будівлі $21 \times 62$ м проведена реконструкція, де відгодовується 160 голів молодняку великої рогатої худоби (рис.1).
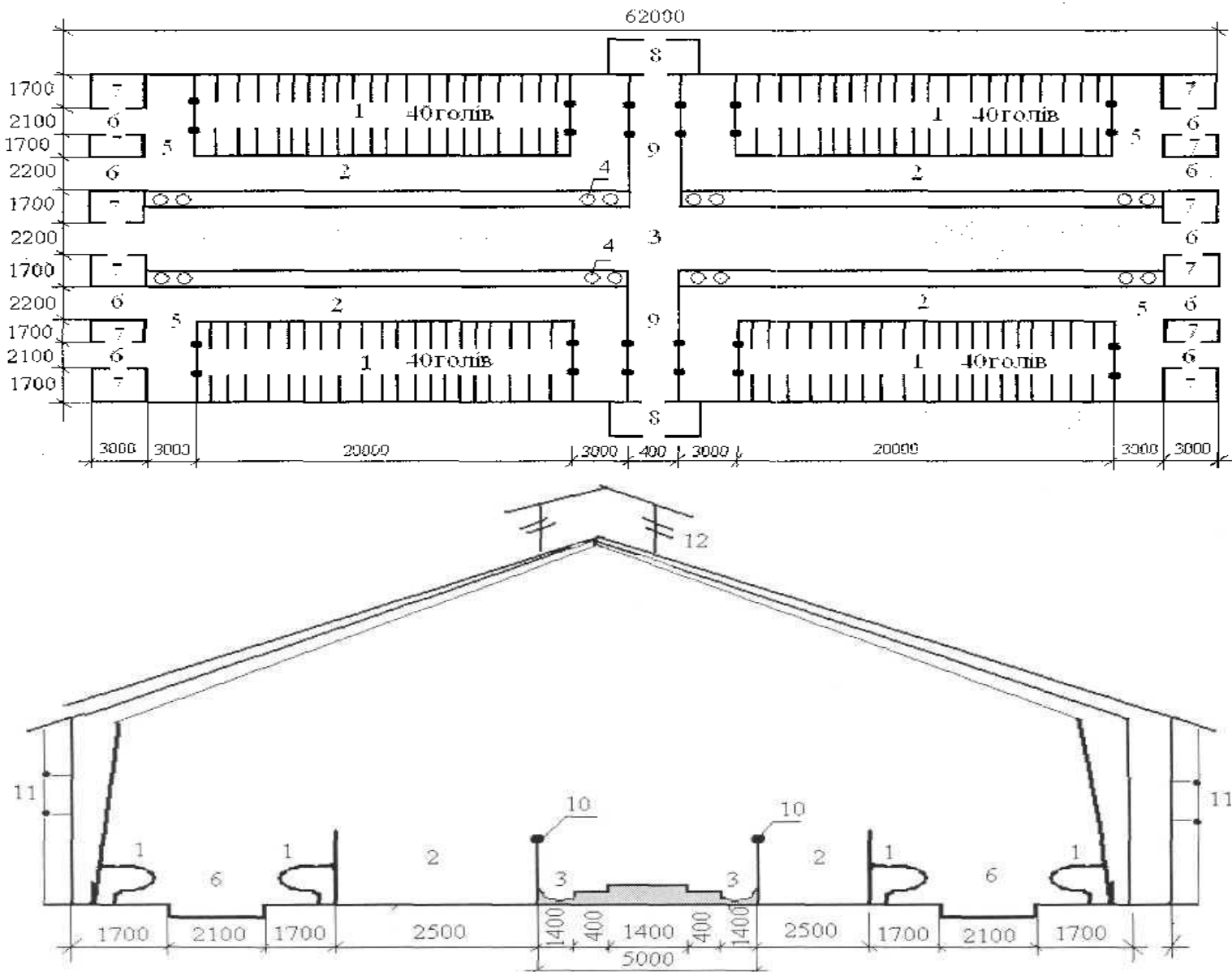

Рис.1. Схеми плану та розрізу телятника для виробництва яловичини на 160 голів молодняку великої рогатої худоби 
1 - секція на 40 голів безприв'язного утримання у боксах; 2 - зона годівлі; 3 - годівельний стіл; 4 - автонапувалки; 5 - технологічні проходи; 6 - гнойовий прохід; 7 - допоміжні приміщення; 8 - тамбур; 9 - технологічний прохід; 10 - годівельна перегородка; 11 - штори; 12 - вентиляційний канал; 13 - зона відпочинку (бокс).

Другим важливим фактором ефективного виробництва яловичини є своєчасне прибирання тваринницьких приміщень та видалення гною, ефективне використання його - одна 3 важливих народногосподарських проблем, значення якої зростає в міру підвищення рівня концентрації виробництва продукції тваринництва та технічного оснащення ферм, а також вимог до санітарногігієнічних умов утримання тварин і якості продукції, що виробляється. При вирішенні проблеми прибирання та утилізації гною необхідно забезпечувати: фізіологічний комфорт в зоні утримання тварин, екологічну безпеку навколишнього середовища, ефективне використання гною, в першу чергу, як органічного добрива та використання виробництва біогазу.

Ця проблема охоплює три складних завдання: прибирання тваринницьких приміщень $\mathrm{i}$ видалення гною в сховища; його складування, знезараження та зберігання; переробка i використання гною.

При проектуванні систем прибирання, видалення, обробки та використання гною слід враховувати прогресивні технології і дотримуватися умов, які забезпечують:

- повне використання всіх видів гною та його складових безпосередньо як органічного добрива для сільськогосподарських угідь або ж як сировини для виробництва комплексних органо-мінеральних добрив чи інших виробничих потреб та альтернативних видів палива;

- виконання ветеринарних і санітарно-гігієнічних вимог експлуатації тваринницьких підприємств при мінімальних витратах води, а також вимог законодавства щодо охорони навколишнього середовища;

- підвищення рівня механізації та автоматизації виробничих процесів.

Особливу увагу необхідно приділяти правильному вибору технології і способів видалення гною $з$ тваринницьких приміщень, оскільки від цього залежать капіталовкладення в споруди та технічні засоби для його подальшої обробки, а також експлуатаційні витрати, пов'язані з утилізацією гною.

Технологією передбачено безприв'язне утримання молодняку великої рогатої худоби 3 відпочинком у боксах. Важливим конструктивним елементом даного технологічного проекту $\epsilon$ обладнання природної вентиляції. Мікроклімат підтримується природною вентиляцією, застосуванням шторок та світлово-вентиляційного ліхтаря. Передбачено розміщення зони годівлі у центральній частині приміщення, яка складається з годівельного столу, направляючих місць для коліс, годівниці для корів, годівельної решітки та майданчика біля годівельної решітки. Зона годівлі за шириною приміщення займає 10 м або 47,6\%.

У зоні відпочинку, яких у приміщенні дві, з обох сторін приміщення, обладнані бокси шириною 1,0 м для кожної тварини і довжиною (глибиною) - 1,7 м. Розміщення тварин у зоні відпочинку в 4 секціях по 40 голів, у двох рядах боксів. Загальна довжина кожної зони 20 м. Для вільного проходу тварин у зону годівлі і у зоні відпочинку обладнано два технологічних проходи у кожній секції.

Умови утримання направлені на поведінку відгодівельного молодняку, у якого високий апетит та можливості його задоволення без конкурентної боротьби. Таке важливе значення має забезпечення тварин постійними кормами у зоні їх годівлі. Всі заходи актуальні і відповідають нормам технологічного проектування, які використовуються у розробках даної реконструкції діючої тваринницької будівлі.

Важливим за даною технологією виробництва яловичини є високий рівень використання виробничих площ. Так, загальна площа будівлі $1302 \mathrm{~m}^{2}$, або на кожну голову 8,14 м. У технологічному процесі використовуються $1176 \mathrm{~m}^{2}$ або 90,3\% від загальної площі. Значна концентрація худоби у приміщенні приводить у чотирьох зонах до накопичення сечі та гною на загальній площі 515,2 м², що складає біля 40\% від площі будівлі. Тому потребується особливого підходу до створення комфортних умов утримання молодняку великої рогатої худоби. Для покращення мікроклімату обладнано спеціальний вентиляційно-світловий ліхтар та на стінах встановлені штори, які можуть за потребою відкриватись або закриватись, що успішно застосовано у даному технологічному процесі.

Встановлено, що роздача добової потреби корму у годівельний стіл зменшує в 2-3 рази затрати на даний технологічний процес. 
У даній будівлі працює один механізатор, який доставляє корми і видаляє гній бульдозером у поруч розміщене гноєсховище.

Другий працівник охороняє тварин і контролює загальний стан тварин у приміщенні, відповідає за підтримкою мікроклімату та розміщенням кормів біля передньої стінки годівельного столу. У підсобних приміщеннях є необхідний реманент, за допомогою якого черговий працівник очищає годівельний стіл від не використаного тваринами корму.

Економічна оцінка відгодівлі молодняку великої рогатої худоби показала суттєві переваги використання годівельних столів, безприв'язного боксового утримання та видалення гною бульдозером (табл.1).

Таблиця 1. Економічна ефективність відгодівлі молодняку великої рогатої худоби безприв'язно у боксах з годівлею у годівельного столу (на одну голову)

\begin{tabular}{|l|c|c|c|}
\hline \multicolumn{1}{|c|}{ Показники } & Прив'язний & $\begin{array}{c}\text { Безприв'язний } \\
\text { боксове із } \\
\text { годівельним } \\
\text { столом }\end{array}$ & $\begin{array}{c}\text { Безприв'язне y } \\
\text { \%о до } \\
\text { прив'язного }\end{array}$ \\
\hline Розмір будівлі, м & 12 х 62 & 12 х 62 & 100 \\
\hline Кількість головомісць, голів & 100 & 160 & 160 \\
\hline Жива маса при постановці, кг & 277 & 280 & 101,1 \\
\hline Жива маса при знятті з відгодівлі, кг & 415,2 & 432,1 & 104,1 \\
\hline $\begin{array}{l}\text { Середньодобовий приріст живої маси, } \\
\text { г }\end{array}$ & 768 & 845 & 110,0 \\
\hline Приріст живої маси, кг & 138,2 & 152,1 & 110,0 \\
\hline $\begin{array}{l}\text { Всього затрати корму за відгодівлю, } \\
\text { корм. од. }\end{array}$ & 1714 & 1804 & 95,2 \\
\hline $\begin{array}{l}\text { Затрати кормів на 1 кг приросту живої } \\
\text { маси, корм.од }\end{array}$ & 12,4 & 11,8 & 42,2 \\
\hline $\begin{array}{l}\text { Затрати праці на одну голову за період } \\
\text { відгодівлі, люд. - год. }\end{array}$ & 11,7 & 4,94 & 38,4 \\
\hline $\begin{array}{l}\text { Затрати праці на 1 ц. приросту живої } \\
\text { маси, люд.-год. }\end{array}$ & 8,47 & 3,25 & 103,4 \\
\hline Реалізаційна ціна 1кг живої маси, грн. & 23,20 & 24,0 & 107,6 \\
\hline Виручка від реалізації, грн. & 9632,2 & 10370,4 & 93,1 \\
\hline Виробничі затрати за весь період, грн. & 8312,4 & 7742,2 & 18,31 \\
\hline Прибуток, грн. & 1300 & 2628,2 & 33,95 \\
\hline Рівень рентабельності, \% & 15,64 & & \\
\hline
\end{tabular}

3 даних таблиці 1 видно, що при розміщенні молодняку в приміщеннях $12 \times 62$ м, але при різних видах утримання отримаємо такі результати: при прив'язному утриманні середньодобові прирости складають 768 г, а при безприв'язному 845 г, що на 9,1\% більше, ніж за прив'язного.

Прирости живої маси за прив'язного утримання склали 138,2 кг., а за безприв'язного 152,1 кг, що на 9,1\% більше, ніж за прив'язного. Затрати кормів на 1кг приросту живої маси на $4,8 \%$ менші при безприв'язному способі утримання ніж прив'язному способі утримання. Затрати праці на одну голову за період відгодівлі за прив'язного утримання склали 11,7 люд. год., а за безприв'язного - 4,94 люд. - год., що в 2,3 рази більші, ніж за безприв'язного.

Утримання тварин спроектовано за умов двостадійного вирощування (рис. 2). Проектно-інноваційні схеми виконували за даними літературних джерел Л.В. Польовий та ін. [7], Г.В. Гетун [4] В.Г. Пруднікова [9], де приведені різні варіанти проектних розробок.

Виробничі затрати за весь період вирощування за прив'язного способу більші на 6,9\% порівняно з безприв'язним способом. Рівень рентабельності за прив'язного способу утримання нижчий на $18,3 \%$, порівняно з безприв'язним, що свідчить про значну перевагу технології.

Отже, отриманні результати вказують на те, що за сучасних умов виробництва тваринницької продукції використання діючих норм технологічного проектування дозволяє ефективно використати тваринницькі будівлі, в яких успішно можна виробляти яловичину 3 мінімальними енергетичними витратами кормів, прибирання гною та підвищувати продуктивність молодняку на м’ясо. 

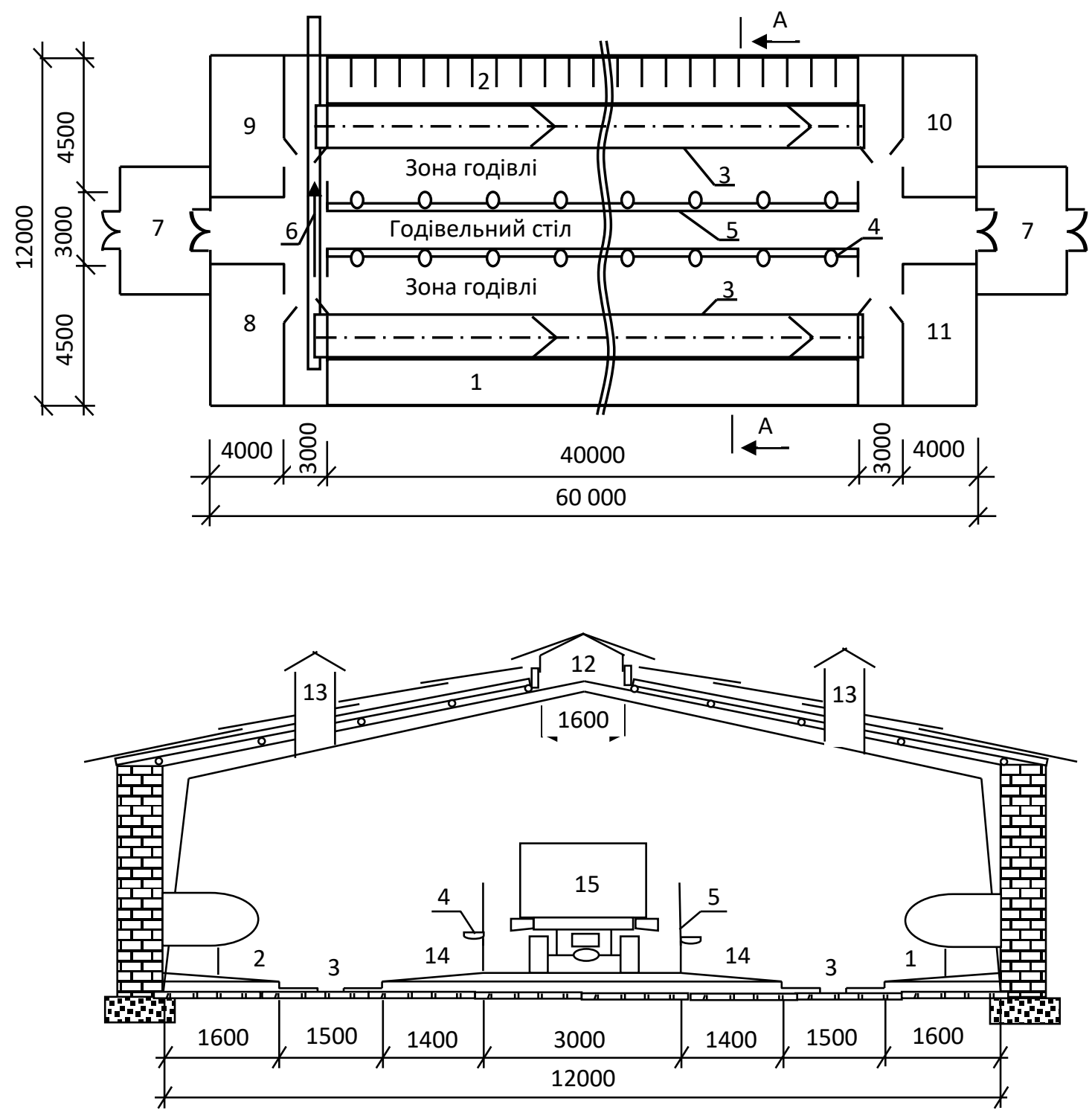

Рис. 2. Схема плану та розрізу приміщення для утримання дослідної групи надремонтного молодняку з 9- до 15-18-місячного віку - рамна конструкиія (II стадія технології)

1, 2- зони відпочинку у боксах; 3- гнойовий транспортер; 4- автонапувалка; 5- годівельна перегородка; 6- допоміжний транспортер для видалення гною; 7- тамбур; 8-11- допоміжні приміщення; 12- світловий ліхтар; 13- вентиляційна шахта; 14- зона годівлі; 15кормороздавач для роздавання кормів на годівельний стіл.

Виробництво яловичини за безприв'язного утримання худоби на початку відгодівлі $\epsilon$ визначальним показником. Тому забезпеченість тварин у різні вікові періоди повноцінною годівлею має вирішальне значення, що й було передбачено дослідженнями.

Відбирали тварин у групи за живою масою за принципом груп-аналогів у кінці 2місячного віку, з 3 до 8 місяця їх утримували на годівельних майданчиках і поділяли на дві групи. Початок цього періоду припадав на березень-квітень.

Зміна показників живої маси на кінець періодів наведено у рисунок 3 .

Із даних діаграми (рис. 3) видно, що двостадійна технологія більш ефективна. Особливо це видно за показниками живої маси на кінець періоду за двостадійної технології, що на 64,2 кг або 15,8\% більше, ніж за трьох стадійної технології виробництва яловичини.

За тристадійної технології середньодобові прирости до 616 г, а за двостадійної - на 220 г більші.

Параметри мікроклімату у приміщенні для утримання надремонтного молодняку у зимовий та перехідний період великої рогатої худоби при порівнянні із нормативними даними [2] (табл. 2). 


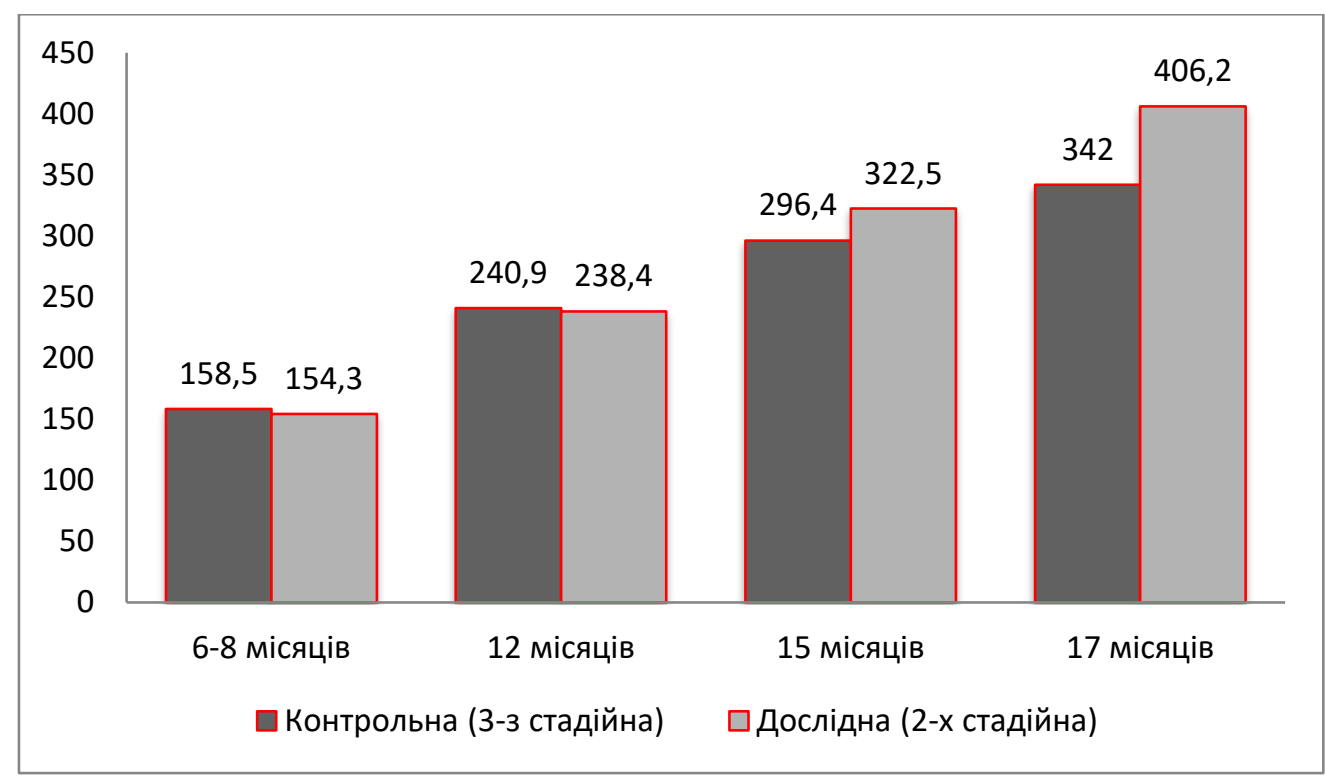

Рис. 3. Жива маса над ремонтних бичків на кінещьь періоду за різних технологій

Таблиця 2. Порівняльні показники мікроклімату в зимово-перехідний період

\begin{tabular}{|c|c|c|c|c|}
\hline \multirow{3}{*}{ Показник } & \multicolumn{4}{|c|}{ Технологічні групи тварин } \\
\hline & \multicolumn{2}{|c|}{ молодняк до року } & \multicolumn{2}{|c|}{ молодняк старше року } \\
\hline & норма & дослід & норма & дослід \\
\hline $\begin{array}{l}\text { Температура повітря в зимовий i } \\
\text { перехідний період, }{ }^{\circ} \mathrm{C}\end{array}$ & $8-16$ & $10,9 \pm 0,42$ & $8-16$ & $12,4 \pm 0,53$ \\
\hline 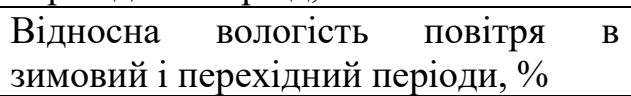 & $70-75$ & $76 \pm 2,43$ & $70-75$ & $77 \pm 4,13$ \\
\hline $\begin{array}{l}\text { Швидкість руху повітря, м/с: } \\
\text { Зимово-перехідний період }\end{array}$ & $0,3-0,5$ & $0,4 \pm 0,12$ & $0,3-0,5$ & $0,5 \pm 0,11$ \\
\hline Вміст вуглекислого газу, \% & до 0,20 & $0,22 \pm 0,05$ & до 0,20 & $0,23 \pm 0,06$ \\
\hline Вміст аміаку, мг/м ${ }^{3}$ & до 20 & $18,4 \pm 1,12$ & до 20 & $17 \pm 1,17$ \\
\hline Атмосферний тиск, мм рт. ст. & 760 & $760,6 \pm 1,08$ & 760 & $759,8 \pm 1,90$ \\
\hline
\end{tabular}

Отже, із даних таблиці 2 видно, що мікроклімат тваринницьких приміщень дещо порушено, а саме: за вмістом вуглекислого газу перевищено на $0,02 \%$ та $0,03 \%$, та відносної вологості на $1 \%$ та $2 \%$. Показники температури, відносної вологості та атмосферного тиску у межах норми.

Також спостерігається тенденція поступового зростання приростів за двостадійної технології та спадання, зростання і знову спадання за тристадійної технології.

Ефективність виробництва яловичини залежить від технології виробництва та отриманих приростів за період вирощування (табл. 3).

Таблиця 3. Економічна ефективність виробництва яловичини за різних технологій

\begin{tabular}{|l|c|c|c|}
\hline \multicolumn{1}{|c|}{ Показники } & $\begin{array}{c}\text { Контрольна } \\
\text { (3-х стадійна } \\
\text { технологія) }\end{array}$ & $\begin{array}{c}\text { Дослідна (2-х } \\
\text { стадійна } \\
\text { технологія) }\end{array}$ & $\begin{array}{c} \pm \text { дослід до } \\
\text { контролю }\end{array}$ \\
\hline Поголів'я при постановці, голів & 16 & 16 & - \\
\hline Жива маса при постановці у групу, ц & 13,54 & 13,22 & $-0,32$ \\
\hline Тривалість періоду утримання, діб & 480 & 480 & - \\
\hline Середньодобовий приріст, г & 536 & 686 & 150 \\
\hline В кінці відгодівельного періоду, голів & 16 & 16 & - \\
\hline Абсолютний приріст, ц & 41,18 & 52,70 & 11,52 \\
\hline Реалізаційна жива маса, ц & 54,72 & 65,92 & 11,20 \\
\hline Затрати кормів на 1ц приросту, ц корм. од. & 12,8 & 11,2 & $-1,6$ \\
\hline Виручка від реалізації, тис. грн. & 65,66 & 79,10 & 13,44 \\
\hline Прибуток, тис. грн. & 6,57 & 19,77 & 13,20 \\
\hline Рівень рентабельності, \% & 11,1 & 33,3 & 22,2 \\
\hline
\end{tabular}


3 даних таблиці 3 видно, що середньодобові прирости живої маси у контрольній групі складали 536 г, що менше, ніж у дослідній на 21,86\%. У результаті цього і відбулися перевитрати кормів на 1 ц приросту живої маси (на 14,28\%) у порівняні із контрольною групою, тому і виробничі витрати склали 1,08 тис. грн., що більше на 20\%, ніж за двостадійної технології виробництва яловичини від надремонтного молодняку української чорно-рябої молочної породи.

Отже, проведені дослідження свідчать про те, що 3-х стадійна технологія з виробництва яловичини на рівні рентабельності $11,12 \%$, тоді як за 2-х стадійної технології рентабельність вища на $22,2 \%$.

Висновки: 1. Застосування 2-х стадійної технології вирощування надремонтного молодняку великої рогатої худоби дозволяє збільшити живу масу тварин та отримати в 17 місячному віці - 406,2 кг, що більше на 64,2 кг або 15,8\%, порівнюючи із застарілою 3-х стадійною технологією, що забезпечує вищу прибутковість на рівні рентабельності виробництва яловичини $33,3 \%$, що більше на $22,2 \%$.

2. Доцільно впроваджувати у виробництво 2-х стадійну технологію виробництва яловичини за умов утримання надремонтного молодняку безприв'язно з відпочинком у боксах.

3. Порівняльна оцінка прив'язного способу утримання молодняку великої рогатої худоби 3 безприв'язним у боксах показала, що безприв'язний варіант: затрати кормів були меншими на $5,2 \%$, а затрати праці - на 57,8\%, за рівня рентабельності, який був вищим на $18,31 \%$.

4. Пропозиція виробництву використовувати діючі безприв'язний спосіб утримання 3 відпочинком тварин у боксах для відгодівлі молодняку великої рогатої худоби з використанням годівельних столів, із затратами кормів на 1 кг приросту живої маси 12 корм. од. та затратами праці на 1 ц. приросту живої маси - 3,25 люд. - год.

\section{REFERENCES}

1. Varpikhovskyi, R.L. (2017). Efektyvnist vykorystannia zemelnoi dilianky tovarno-molochnoi fermy maloi potuzhnosti za riznykh sposobiv utrymannia [The efficiency of land use, commodity-dairy farm of low power at different ways to keep]. Ahrarna nauka ta kharchovi tekhnolohii / Redkol. V.A. Mazur (hol. red.) ta in. Vinnytsia: VTs VNAU [in Ukrainian].

2. Vidomchi normy texnolohichnoho proektuvannia: Skotarski pidpryiemstva (kompleksy, fermy, mali fermy) [Departmental norms of technological design: Cattle breeding enterprises (complexes, farms, small farms)] (2005). VNTP APK 01.05. - K.: Ministerstvo ahrarnoi polityky Ukrainy, 110 [in Ukrainian].

3. Volkov, Gh.K. \& Danylov, A. N. (2005). Ghyghyena otkorma krupnogho roghatogho skota. [Hygiene of fattening cattle ]. Efektyvne tvarynnyctvo. \#1. [in Ukrainian].

4. Ghetun, Gh.V. (2006). Osnovy proektuvannja promyslovykh budivelj: Navch. posib [Principles of design of industrial buildings]. K.: Kondor. [in Ukrainian].

5. Kononenko, V. K. \& Ibatullin, I.I. \& Patrov, V.S. (2000). Praktykum z osnov naukovyx doslidzhen' u tvarynnytstvi [Workshop on basics of scientific research in animal husbandry]. Kyiv. [in Ukrainian].

6. Patrov, V. S. \& Nedvyha, M.M. \& Pavliv, B.A. (2000). Osnovy variaciinoi statystyky. Biometriia: Posibnyk z henetyky sil's'kohospodars'kyx tvaryn [The basics of variation statistics. Biometrics: a Guide to the genetics of farm animals]. Za red. V. S. Patrova. - Dnipropetrovs'k: Sich. [in Ukrainian].

7. Poljovyj, L.V. \& Poliova, O.L. \& Romanenko, T.D. (2008). Efektyvnistj vyrobnyctva jalovychyny v umovakh riznykh faz tekhnologhichnykh periodiv [The efficiency of beef production in different phases of technological periods]. Zb. nauk. pratc VDAU. Vinnytsia. Vyp. 34. Tom. 1. [in Ukrainian].

8. Ibatullin, I.I. \& Panasenko, Ju.O. \& Kononenko, V.K. (2003). Praktykum z ghodivli siljsjkoghospodarsjkykh tvaryn [Workshop on farm animal feeding]. K.: Vyshha osvita. [in Ukrainian].

9. Prudnikov, V.Gh. (2000). Energhetychna ocinka dvostadijnoji tekhnologhiji intensyvnogho vyroshhuvannja bychkiv dlja vyrobnyctva jalovychyny. [Energy rating technology two-stage intensive rearing of calves for beef production]. Zb. nauk. prac Vinnyckogho derzh. aghrar. universytetu. Vinnycja. Vyp.8, T.1. [in Ukrainian].

10. Tronchuk, I.S. (2008). Fiziologhichni ta tekhnologhichni osnovy intensyfikaciji vyrobnyctva vysokojakisnoji jalovychyny v Ukrajini [Physiological and technological basis for intensification of production of high-quality beef in Ukraine]. Visnyk Poltavsjkoji derzhavnoji aghrarnoji akademiji. \#3. [in Ukrainian]. 